\title{
基于树木年轮信息的宝天曼不同径级华山松碳储量 动态变化
}

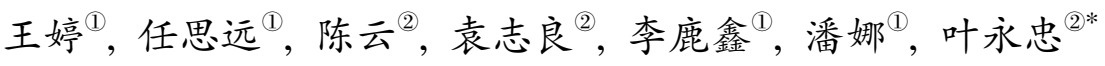 \\ (1) 河南农业大学林学院, 郑州 450002; \\ (2) 河南农业大学生命科学学院, 郑州 450002 \\ * 联系人, E-mail: yeyzh@163.com \\ 2014-07-25 收稿, 2014-09-05 接受, 2014-10-20 网络版发表 \\ 国家自然科学基金(31270493)和植被与环境变化国家重点实验室 2012 年开放课题(LVEC-2012kf06)资助
}

\begin{abstract}
摘要 基于树木年轮学方法, 本文分 3 个不同径级研究了宝天曼自然保护区华山松碳储量的动态 变化. 研究发现: (1) 随着径级的增大, 小径级 $\mathrm{A}(\mathrm{DBH} \leqslant 15 \mathrm{~cm})$ 、中径级 $\mathrm{B}(15<\mathrm{DBH} \leqslant 25 \mathrm{~cm})$ 和大径 级 $\mathrm{C}(\mathrm{DBH}>25 \mathrm{~cm})$ 华山松碳储量分别为 $2.757,9.211,15.408 \mathrm{t} / \mathrm{hm}^{2}$, 它们年均增加的碳储量分别为 $0.0685,0.1535,0.136 \mathrm{t} / \mathrm{hm}^{2} ;$; (2) 中径级华山松林分密度和径向生长量最大, 其年均碳储量增长量 大于大径级华山松和小径级华山松; (3) 大径级华山松每年碳储量增长量决定着华山松林总碳储 量的变化. 个体死亡率是限制中小径级华山松碳储量增长的重要因素, 树木生理生长的影响是限 制大径级华山松碳储量增加的主要因素。研究结果表明, 利用树木年代学序列能较好地探讨宝天 曼华山松生长趋势和评估碳储量的动态变化.
\end{abstract}

关键词

华山松

树木年轮

不同径级

碳储量

动态变化
工业化发展、人口剧增、化石燃料的大量使用和 对森林的过度采伐, 使得大气 $\mathrm{CO}_{2}$ 浓度增加, 造成温 室效应等一系列全球性生态问题 ${ }^{[1]}$. 森林植物能吸收 大气中的 $\mathrm{CO}_{2}$ 并将其固定在植被或土壤中, 从而减少 $\mathrm{CO}_{2}$ 在大气中的浓度, 森林生态系统在监控陆地生态 系统的气候变化、碳储量动态方面有着不可替代的作 用. 人们尝试将人为排放的碳转人森林生态系统, 降 低温室气体排放量, 可以减缓全球变暖的进程 ${ }^{[2]}$.

森林生物量和碳储量动态变化研究有助于揭示 气候变化和植被之间的关系, 充分理解和认识森林 在不同恢复过程中的林分生物量及其动态特征, 对 全球碳循环评估意义重大 ${ }^{[3]}$. 碳储量的研究方法主要 有样地调查法 ${ }^{[4]}$ 、通量观测法 ${ }^{[5]}$ 、模型模拟法 ${ }^{[6]}$ 、遥 感估算法 ${ }^{[7]}$ 和树木年轮法 ${ }^{[8]}$. 样地调查法是通过建立 永久样地, 每年、或者 5 或 10 年对胸径和树高等一 些因子调查来计算碳储量, 但是该方法耗时长、投人
量大; 通量观测法直接对森林与大气之间的通量进 行计算, 却成本高、范围小, 而且只能估算当年的碳 储量; 模型模拟法是通过建立数学模型, 综合模拟植 被的光合作用和呼吸作用以及它们与环境间的相互 关系, 来估算森林生态系统的净初级生产力和碳储 量. 相关方法能够获取森林长期累积的 ${ }^{[4]}$ 或当年的 ${ }^{[5]}$ 生物量和碳储量, 然而对获取森林发育过程中的生 物量和蓄积量动态信息较为困难.

树木年轮记录了树木每年生长的丰富信息, 能 够提供较为详细的年分辨率数据 ${ }^{[9,10]}$, 是估算森林生 物量及碳蓄积量的有用信息源 ${ }^{[1113]}$. 研究表明, 树 木年轮分析法在对一些树种年增长率进行回顾性评 估时的数据精确度高于其他评估法 ${ }^{[14]}$. 邵全琴等 人 ${ }^{[15]}$ 尝试用树木年轮法创建 TGTRing 模型探讨江西 千烟洲几种针叶树人工林乔木层每年生物量和碳蓄 积量的变化; Liu 等人 ${ }^{[16]}$ 和张远东等人 ${ }^{[17]}$ 基于树木年

引用格式: 王婷, 任思远, 陈云, 等. 基于树木年轮信息的宝天曼不同径级华山松碳储量动态变化. 科学通报, 2014, 59: 3499-3507

Wang T, Ren S Y, Chen Y, et al. Dynamic of carbon storage of Pinus armandii forest at different diameter levels based on tree ring data in the Baotianman National Nature Reserve, central China (in Chinese). Chin Sci Bull (Chin Ver), 2014, 59: 3499-3507, doi: 10.1360/N972014-00403 
轮法对川西亚高山林区不同恢复途径下森林乔木层 生物量和碳储量进行了研究. 相关研究表明, 树木年 轮法可用在森林碳动态研究中 ${ }^{[18 ~ 20]}$, 监控森林不同 演替阶段生物量和碳储量的变化.

利用树木年轮法评估森林生物量和碳储量变化 的相关研究大都是基于调查树木当前的胸径和树高 生长量, 对不同生长时期进行研究的比较少, 树木不 同生长时期胸径和树高的生长速率是不同的 ${ }^{[21]}$. 森 林中树木的径级结构是林木更新过程快慢的反映 ${ }^{[22]}$, 也是林木种群不同生长时期的反映. 忽略树木不同 生长时期的碳动态变化会增加森林碳储量估算结果 的不确定性.

华山松(Pinus armandii) 是河南省伏牛山、太行山 较高山地重要针叶树种之一, 对当地的森林生态系 统有着重要作用. 宝天曼国家自然保护区地处伏牛 山南坡, 属南暖温带-北亚热带过渡区, 区内森林覆 盖率高达 97.8\%, 华山松主要分布于海拔 1600 1750 $\mathrm{m}$ 的垂直范围, 和锐齿檞係组成针阔叶混交林. 本文 以宝天曼华山松为研究对象, 尝试以树木年代序列 为基础, 探讨不同径级华山松碳储量的动态变化, 进 而获得华山松林年际碳储量的动态特征, 以期准确 评价不同生长时期华山松碳储量的动态, 为进一步 研究不同演替过程森林生态系统碳碳储量动态提供 理论依据.

\section{1 资料与方法}

(i) 野外调查取样. 本实验所设置的 $1 \mathrm{hm}^{2}$ 华 山松样地 $\left(33.49^{\circ} \mathrm{N}, 111.94^{\circ} \mathrm{E}\right.$, 海拔 $\left.1508 \mathrm{~m}\right)$, 属于宝 天曼暖温带落叶阔叶林 $25 \mathrm{hm}^{2}$ 固定监测样地的卫星 样地, 位于伏牛山脉宝天曼国家级自然保护区内, 地 处暖温带向北亚热带过渡区. 区域内生境类型多样、 物种丰富, 是生物资源的天然基因库. 宝天曼年均气 温 $15.1^{\circ} \mathrm{C}$, 年均降水量 $885.6 \mathrm{~mm}$, 土壤可划分为山 地棕壤、山地黄棕壤和山地褐土 3 种, 土壤 $\mathrm{pH}$ 为 6.5 左右.

本研究对 DBH (树高 $1.3 \mathrm{~m}$ 处的胸径) $\geqslant 1 \mathrm{~cm}$ 的 华山松进行每木尺检, 分别记录胸径、树高、冠幅、 郁闭度. 按照样地调查资料, 将样地内华山松按 5 $\mathrm{cm}$ 划分径级, 在样地外每个径级选 2 4 株华山松钻 取树芯，在树高 $1.3 \mathrm{~m}$ 处分别沿与向阳面山坡等高线 方向平行和垂直 2 个方向钻取树芯, 每棵树钻取 2 个 树芯, 共采集 8 个径级 27 棵华山松的树芯共 54 个.
测量树芯长度后装于特制塑料软管中, 贴好标签, 记 录树高、胸径和样芯质量等信息.

(ii) 树木年轮样芯宽度测量与校正. 为防止时 间过长引起树芯发需, 将野外钻取的树芯带回实验 室后从塑料管中倒出, 待其自然风干后对树芯重新 测量长度, 以确定缩水率. 经测定, 树芯风干引起的 干缩不大, 在生物量计算中未对此部分误差进行校 正. 将自然风干后的树芯用白乳胶固定在带有凹槽 的细木条上, 树芯黏牢后, 依次用砂粒分别为 240 , 320,500 目的砂纸打磨抛光, 直至显微镜下能够清晰 地分辨细胞大小. 使用树木年轮测量仪 Lintab5 测量 树芯的年轮宽度值, 精确到 $0.001 \mathrm{~mm}$, 用 $\mathrm{COFFCHA}$ 进行交叉定年检验以甄别系统定年错误和测量误差.

由于钻取的树芯轮宽值累加得到的模拟胸径值 与实测的胸径值之间存在一定的偏差, 需要对树芯 宽度进行校正 ${ }^{[5]}$. 校正公式为

$$
\begin{gathered}
\theta=\frac{\left(D_{\mathrm{bh}}-D_{i}\right)}{2 n}, \\
D_{n}=d_{n} \pm \theta,
\end{gathered}
$$

$\theta$ 为校正值 $(\mathrm{mm}), D_{\mathrm{bh}}$ 为实测胸径值, $d_{n}$ 为实测的树芯 轮宽值, $D_{i}$ 为轮宽值 $d_{n}$ 累加得到的胸径值, $n$ 为树龄, 树芯年轮宽度实际测量值加上 $\theta$ (可正、可负)得到校 正后的年轮宽度值 $D_{n}$. 累加树芯的年轮宽度值得到 的胸径值没有包括树皮，在计算胸径时将现存树皮 厚度估算为胸径的一部分.

（iii）华山松年龄的确定. 利用样地外所取得华 山松树芯的年龄和树木胸径，结合宝天曼国家级自 然保护区保存的本样地附近解析木胸径处树盘数据, 建立华山松的年龄-胸径拟合方程，进而利用所测量 的样地内华山松的胸径值估算所有华山松的树龄. 不同树龄树木自身的生长趋势不同 ${ }^{[23]}$, 导致不同树 龄树木的树高和胸径增长量也不同, 研究华山松年 均生长变化, 需了解各个时段华山松生长趋势. 根据 华山松的生长规律, 胸径和树高的年均增长在 50 年 前后达到第一个高峰, 胸径累计生长达到 $13 \mathrm{~cm}$ 左右, 此后生长缓慢; 材积生长前 50 年渐快, 而后生长缓 慢, 71 80 年出现年均生长第二个高峰, 胸径累计生 长达到 $25 \mathrm{~cm}$ 左右 ${ }^{[24]}$. 根据华山松的生长情况和样地 的调查情况，把宝天曼华山松按胸径分为 $\mathrm{A}$ $(\mathrm{DBH} \leqslant 15 \mathrm{~cm}), \mathrm{B}(15 \mathrm{~cm}<\mathrm{DBH} \leqslant 25 \mathrm{~cm}), \mathrm{C}(\mathrm{DBH}>25$ $\mathrm{cm}) 3$ 个不同的径级. 样地的基本情况见表 1 . 由表 1 中可以看出, 中径级华山松的密度要远高于小径级 
和大径级华山松的密度.

(iv) 华山松胸径的累计生长. 树木年轮能够真 实记录树木每一年的生长情况, 胸径处树芯年轮宽 度的累加值可作为树木当年的胸径值.

$$
D_{\text {ic }}=2 \sum_{j=i}^{n} D_{n},
$$

式中 $D_{\mathrm{ic}}$ 为根据树芯年轮宽度模拟的树木胸径值, $D_{n}$ 为校正后第 $n$ 年的轮宽值, $D_{n}$ 累加后乘以 2 即得到模 拟的胸径值 $D_{\mathrm{ic}}, j$ 为样地每株树的初始年代, 因本文 所用的样芯都是 2010 年钻取的, 故上式中 $n$ 为 2010 .

( V ) 华山松生物量和碳储量动态变化计算. 华 山松生物量 $(W)$ 计算采用陈存根 ${ }^{[25]}$ 统计的全国华山 松生物量异速生长方程. 根据文献资料收集到的秦 岭-伏牛山地区华山松的异速生长方程计算单株地上 和地下各器官生物量, 相加得到华山松单株生物量, 单株生物量累加得到样地内华山松的总生物量. 把 得到的华山松树芯按 A $(\mathrm{DBH} \leqslant 15 \mathrm{~cm}), \quad$ B $\quad(15$ $\mathrm{cm}<\mathrm{DBH} \leqslant 25 \mathrm{~cm}), \mathrm{C}(\mathrm{DBH}>25 \mathrm{~cm}) 3$ 个不同的径级进 行整理, 将整理后的华山松树芯轮宽值加减 $\theta$ 修正 后, 把相同径级的轮宽均值作为当年的标准轮宽值, 标准轮宽累加后得到的 $D_{\mathrm{ic}}$ 为第 $n$ 年标准胸径值; 用 实测的胸径、树高数据拟合胸径-树高方程, 把标准 胸径值代人胸径-树高方程计算出标准树高; 把第 $n$ 年标准胸径和标准楖高代人表 2 中的华山松异速生 长模型, 计算出树干、树枝、树叶、树根生物量, 各 器官生物量相加为华山松单木第 $n$ 年的生物量; 第 $n$ 年生物量减去第 $n-1$ 年生物量为第 $n$ 年生物量年增量, 再乘以碳素系数得到年增长碳储量. 不同径级年均 碳储量增长量乘以华山松的株数, 得出不同径级碳 储量的年增长总量.

树木年轮分析法能得到每株树逐年胸径值, 每 年生物量和碳储量的增长量采用以下公式计算

$$
\begin{gathered}
W_{n}=\sum_{j=m}^{i} a \times\left(D^{2} H\right)^{b}, \\
U_{n}=W_{n}-W_{n-1}, \\
C_{n}=U_{n} \times c,
\end{gathered}
$$

$$
\mathrm{BCD}_{i}=C_{n} \times k,
$$

$a$ 和 $b$ 为异速生长模型参数, $n$ 为树龄, $m$ 为不同器官, $D$ 为胸径(包括实测胸径和模拟胸径), $H$ 为树高(包括 实测树高和模拟树高), $W_{n}$ 为华山松 $n$ 年树龄各器官 生物量之和, 即华山松 $n$ 树龄时的生物量; $U_{n}$ 为 $n$ 年 树龄时生物量增长量, $C_{n}$ 为华山松 $n$ 树龄时的碳储量 增长量, $k$ 为华山松的株数, $c$ 为通用碳素系数 0.5 ; 本 研究基于 $1 \mathrm{hm}^{2}$ 的华山松样地, 用 $\mathrm{BCD}_{i}$ (biomass carbon density)作为 $1 \mathrm{hm}^{2}$ 样地内所有 $k$ 株华山松在 第 $n$ 年增长的总碳储量, 进而计算样地的森林碳储量 变化.

\section{2 结果与分析}

\section{1 华山松生长动态变化}

（i ）华山松树龄动态. 根据华山松样芯和树盘 的年龄与利用轮宽值累加得到的胸径值，建立华山 松的胸径-年龄拟合方程(图 1). 把实际测量的树木胸 径值代人图 1 华山松年龄-胸径拟合方程式估算出相 应的树龄，对实际树龄值与通过拟合方程得出的估 算树龄值进行相关性检验，结果达到显著相关 $(r=0.98, P<0.0001)$. 通过胸径-树龄方程和样地内华 山松的胸径值, 得到样地内华山松的年龄动态(图 2). 由表 1 和图 2 可知, 样地内华山松最小楖龄为 29 年, 最大树龄 115 年, 平均树龄为 55 年; 华山松枯木 27 株, 其中, 小径级的华山松 $(\mathrm{DBH} \leqslant 15 \mathrm{~cm})$ 枯木为 15 株, 占小径级总数的 $11.6 \%$; 中径级华山松 $(15 \mathrm{~cm}<$ $\mathrm{DBH} \leqslant 25 \mathrm{~cm})$ 的枯木为 12 株, 占中径级华山松总数的 $6.3 \%$.

由于样地内的幼苗和幼树没有调查, 样地内小 径级华山松平均树龄为 37 年, 占样地内华山松总数 20.5\%; 中径级华山松的树龄为 41 60 年，占样地华 山松总数 $50.1 \%$; 大径级华山松的平均树龄为 78 年, 约占样地华山松总数的 $29.4 \%$. 总的来看, 倒 $\mathrm{J}$ 型的 年龄结构表明宝天曼华山松种群属于增长型种群.

(ii ) 华山松胸径增长动态. 根据树木年轮宽度

表 1 宝天曼华山松调查样地的基本情况

\begin{tabular}{lllcrcr}
\hline \multicolumn{1}{c}{ 径级 } & 平均树龄 $(\mathrm{a})$ & 树龄 $(\mathrm{a})$ & 平均树高 $(\mathrm{m})$ & 树高 $(\mathrm{m})$ & 枯木 $($ 株 $)$ & 密度 $\left(\right.$ 株 $\left./ \mathrm{hm}^{2}\right)$ \\
\hline $\mathrm{A}(\mathrm{DBH} \leqslant 15 \mathrm{~cm})$ & $37 \pm 3$ & $29 \sim 40$ & $8.2 \pm 2.7$ & $1.9 \sim 14.5$ & 15 & 81 \\
$\mathrm{~B}(15 \mathrm{~cm}<\mathrm{DBH} \leqslant 25 \mathrm{~cm})$ & $50 \pm 5$ & $41 \sim 60$ & $13.3 \pm 2.32$ & $7.0 \sim 16.5$ & 12 & 193 \\
$\mathrm{C}(\mathrm{DBH}>25 \mathrm{~cm})$ & $78 \pm 15$ & $61 \sim 115$ & $15.6 \pm 1.38$ & $10.0 \sim 18.0$ & 0 & 103 \\
\hline
\end{tabular}


表 2 华山松异速生长模型 a)

\begin{tabular}{cccc}
\hline 器官 & 异速生长模型 & 决定系数 $\left(R^{2}\right)$ & 文献来源 \\
\hline 树干 & $0.01308\left(D^{2} H\right)^{1.0038}$ & 0.99 & \\
树枝 & $0.0055\left(D^{2} H\right)^{1.0439}$ & 0.97 & [25] \\
树叶 & $0.0011\left(D^{2} H\right)^{1.12566}$ & 0.92 & {$[25]$} \\
树根 & $0.0033\left(D^{2} H\right)^{1.0148}$ & 0.97 & \\
\hline
\end{tabular}

a) $D$ 为胸径, $H$ 为树高

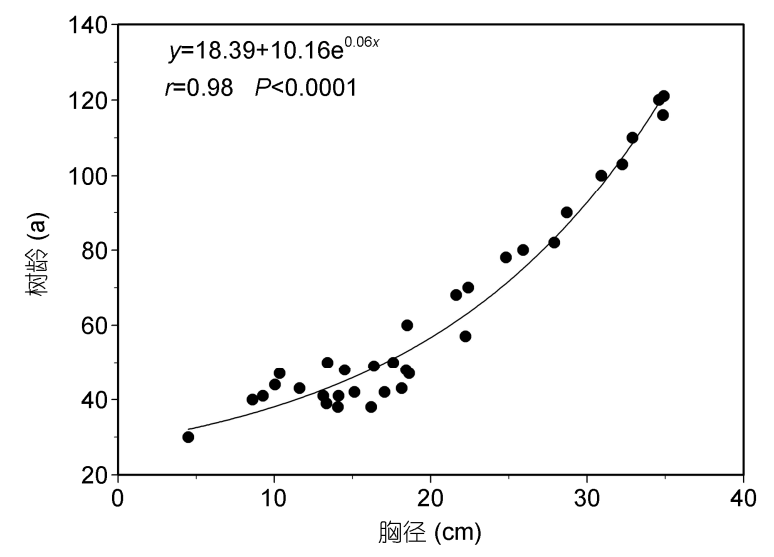

图 1 华山松胸径-年龄的拟合关系

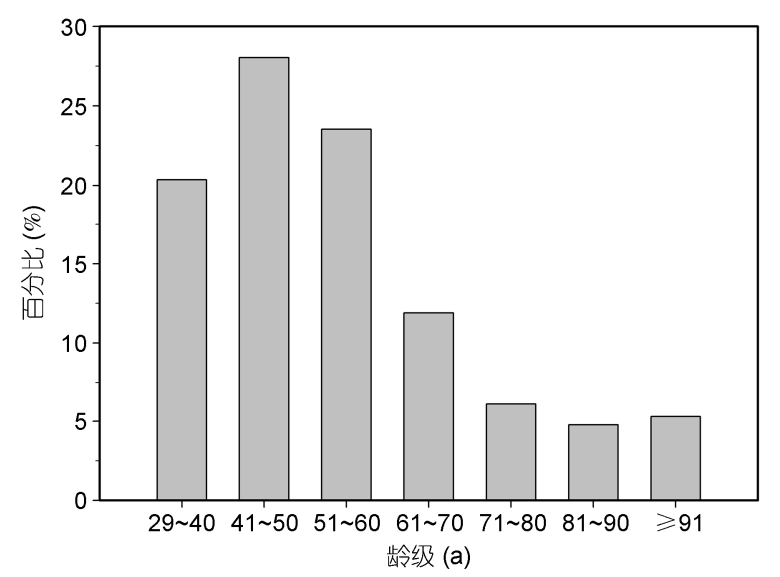

图 2 宝天曼不同华山松的年龄动态

测读仪 Lintab5 测得华山松样芯的年轮宽度, 不同径 级华山松的年轮宽度值分别见图 3. 由图 3 可知, 对 3 个径级华山松年轮宽度进行分析得出, 小径级 $\mathrm{A}$, 中 径级 B, 大径级 C 华山松的平均年轮宽度值不同, 分 别为 $1.504,1.859,1.802 \mathrm{~mm}$. 而 3 个不同径级华山松 的生长趋势相似, 在生命时期的初级阶段年轮宽度 值增长较快, 其中, 中径级华山松平均年轮宽度增长 最快, 年均轮宽值为 $1.86 \mathrm{~mm}$. 不同径级华山松在 1980 年以后生长都较慢, A, B, C 径级华山松胸径在 1980 年以后平均年轮宽度值分别是 $1.35,1.47,0.80$ $\mathrm{mm}$. 总的来看, 中径级华山松胸径处于快速增长阶 段, 大径级华山松增长缓慢.

(iii) 华山松树高生长动态. 根据实测的样地内 华山松胸径和树高数据拟合得到华山松胸径-树高生 长方程, 利用胸径-树龄方程估算出的当年胸径值以 及相应的胸径-树高方程估算出当年的树高值, 以此 来间接建立树龄与树高之间的动态关系. 对树高实 测值和拟合值进行 $T$ 检验(图 4), 研究发现, 华山松 小径级 $\mathrm{A}$, 中径级 $\mathrm{B}$, 大径级 $\mathrm{C}$ 华山松实测平均树高 分别为 $8.2,13.2,15.59 \mathrm{~m}$, 与拟合得到的 3 个生长时 期的估测平均树高分别为 8.74, 12.83, $15.89 \mathrm{~m}$ 之间无 显著差异, 表明生长方程可以用来模拟华山松单木 树高生长过程.

\section{2 华山松生物量和碳储量动态变化}

不同径级宝天曼华山松碳储量年均增长变化见 图 5. 由图 5 可以看出, 小径级华山松的碳储量随树 龄的增加而增长, 年均碳储量增长量是 0.0685 $\mathrm{t} / \mathrm{hm}^{2}$ (图 5A). 中径级华山松年均碳储量增长量是 $0.1535 \mathrm{t} / \mathrm{hm}^{2}$, 随树龄和胸径的增加, 中径级华山松 在 30 年左右年均碳储量增长最快, 随后又有所减慢 (图 5B). 大径级华山松年均碳储量为 $0.136 \mathrm{t} / \mathrm{hm}^{2}$, 碳 储量在 71 80年达到高峰，随着年龄增长出现减低的 趋势(图 5C). 总的来看, 宝天曼华山松林以年均 $0.2422 \mathrm{t} / \mathrm{hm}^{2}$ 的速度增长.

利用实际测量的胸径和树高值代入异速生长方 程(表 2)估算得到宝天曼华山松碳储量为 $27.376 \mathrm{t} / \mathrm{hm}^{2}$, 另一方面, 使用树木年轮法以轮宽累加值得到的胸 径值, 并利用胸径-树高拟合方程计算得到树高值代 入异速生长方程估算得到的碳储量，累加得到宝天 曼华山松地上总碳储量为 $27.377 \mathrm{t} / \mathrm{hm}^{2}$. 以上两种方 法的计算结果基本一致.

研究表明, 华山松在 30 年左右碳储量增长加快 然后减慢, 随后随树龄和胸径的增加而增加, 在 80 年左右达到高峰，这种碳储量增长模式和华山松的 生长趋势紧密相关. 华山松在 20 年后生长加快, 材 积在 50 年前生长极其缓慢, 在 71 80 年达到第一次 生长高峰 ${ }^{[24]}$, 材积的快速增长有利于积累碳储量的 积累.

不同径级华山松随年龄增长的碳储量 $\mathrm{BCD}_{i}$ (biomass carbon density)动态变化见图 6. 由图 6 可以 看出, 华山松胸径随着树龄的增长而增加, 碳密度受 


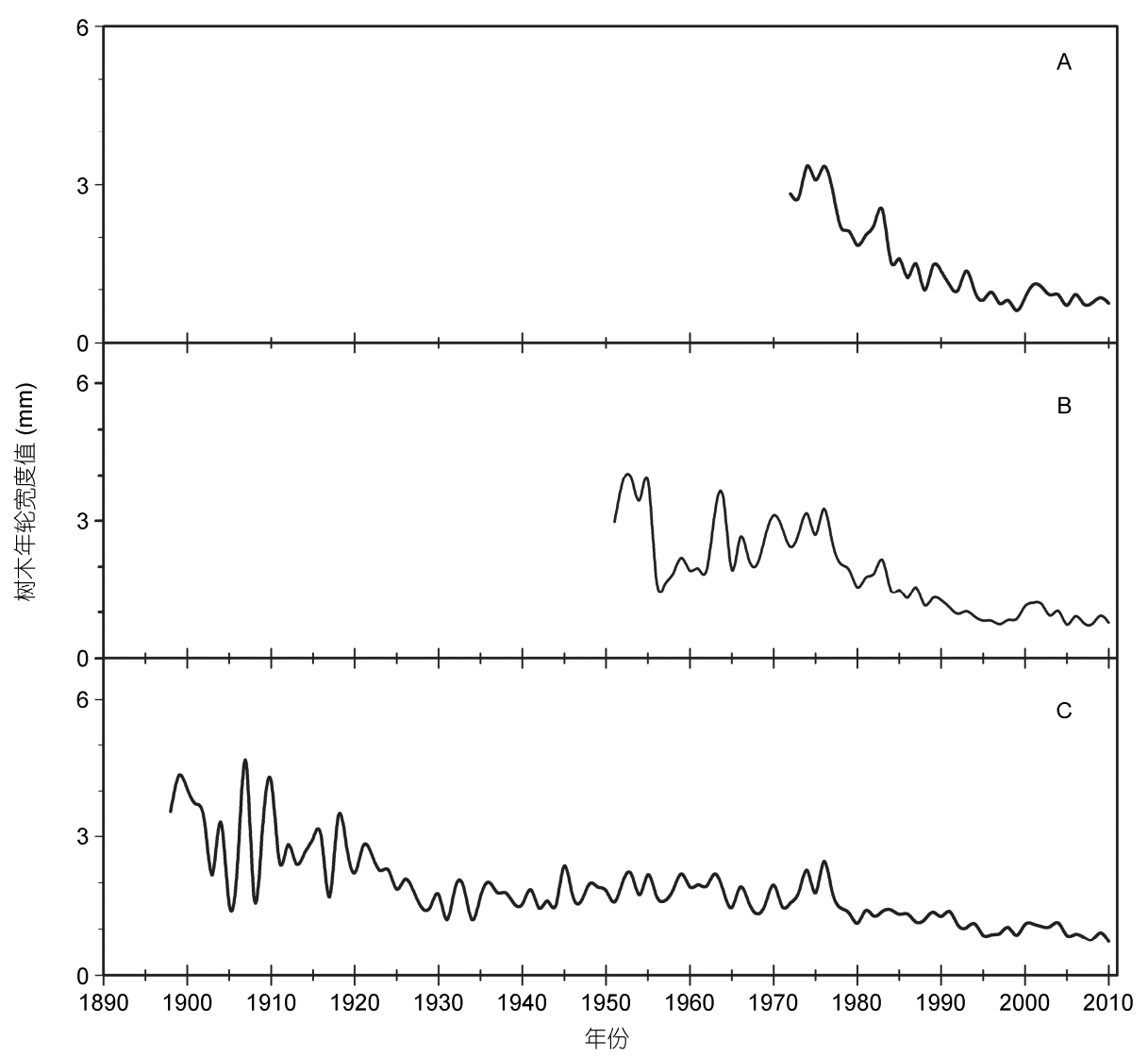

图 3 宝天曼不同径级华山松年均轮宽值

$\mathrm{A}, \mathrm{DBH} \leqslant 15 \mathrm{~cm} ; \mathrm{B}, 15<\mathrm{DBH} \leqslant 25 \mathrm{~cm} ; \mathrm{C}, \mathrm{DBH}>25 \mathrm{~cm}$

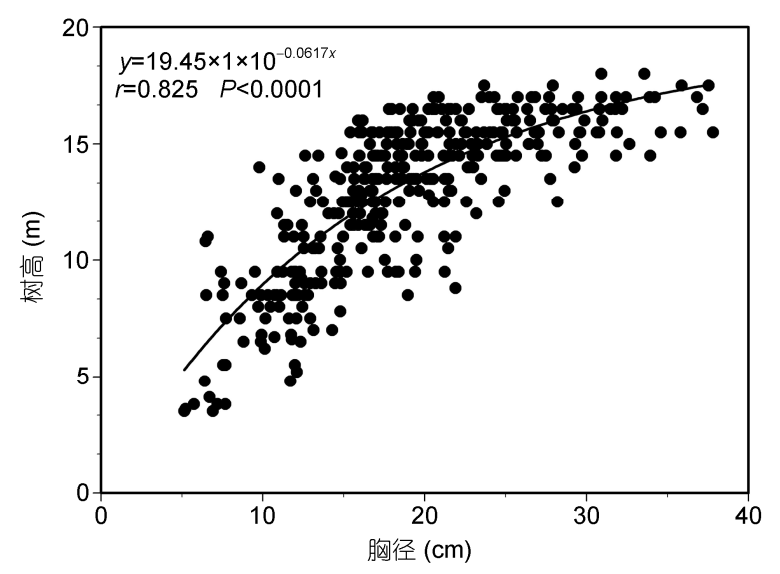

图 4 宝天曼华山松的胸径-树高生长拟合关系

胸径影响出现随树龄增加的趋势, 小径级华山松碳 密度 $\mathrm{BCD}_{i}$ 为 $2.757 \mathrm{t} / \mathrm{hm}^{2}$ (图 6A), 中径级华山松 $\mathrm{BCD}_{i}$ 为 $9.211 \mathrm{t} / \mathrm{hm}^{2}$ (图 6B); 大径级华山松 $\mathrm{BCD}_{i}$ 为 $15.408 \mathrm{t} / \mathrm{hm}^{2}$ (图 6C). 小径级、中径级、大径级华山 松的 $\mathrm{BCD}_{i}$ 分别占样地内华山松总碳储量的 $10.1 \%$,
$33.6 \%$ 和 $56.3 \%$. 大径级华山松碳储量的比重最大, 说明宝天曼华山松碳储量是一个随树龄的累积过程.

为了进一步探讨某一径级华山松碳密度增加量 $\mathrm{BCD}_{i}$ 在当年华山松林总碳储量 $\mathrm{BCD}_{n}$ 中的贡献, 本 文进一步比较了不同径级华山松碳储量 $\mathrm{BCD}_{i} / \mathrm{BCD}_{n}$ 比值(图 7). 研究发现, 随着树龄的变化, 小径级华 山松的 $\mathrm{BCD}_{i} / \mathrm{BCD}_{n}$ 从 0.11 增长到 $0.17,1980$ 年后 $\mathrm{BCD}_{i} / \mathrm{BCD}_{n}$ 都在 0.15 上下波动, 并随树龄增长而增 加, 中径级华山松 $\mathrm{BCD}_{i} / \mathrm{BCD}_{n}$ 从 0.19 增长到 0.43 , 大 径级华山松 $\mathrm{BCD}_{i} / \mathrm{BCD}_{n}$ 从 0.7 减少到 0.45 . 可见, 随 着树龄增加, 华山松小树的胸径和树高增长缓慢, 小 径级华山松每年增加碳储量对华山松林的贡献率变 化不大；中径级华山松的胸径和树高随着树龄的增 大而增长较快, 林分碳储量也随着林龄的增大而增 加; 大径级华山松随林龄增加, 胸径和树高增长减缓, 碳储量受树高和胸径的影响减少. 1980 年后, 大径级 华山松和中径级华山松的 $\mathrm{BCD}_{i} / \mathrm{BCD}_{n}$ 都在 0.45 上下 波动, 大、中径级华山松每年对华山松林碳贡献率相 


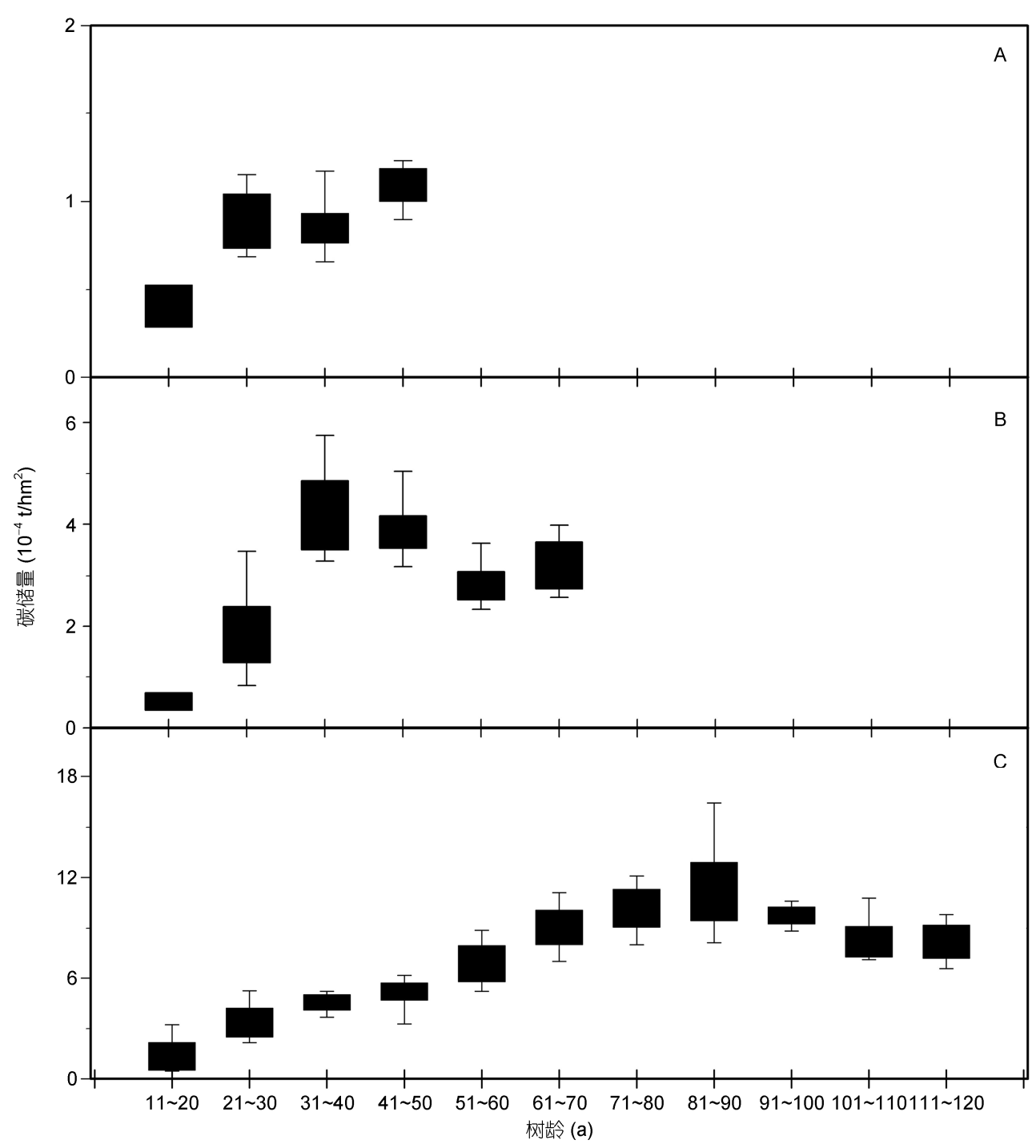

图 5 宝天曼不同径级华山松随年龄增长的碳密度

$\mathrm{BCD}_{i}$ (biomass carbon density)动态变化. $\mathrm{A}, \mathrm{DBH} \leqslant 15 \mathrm{~cm} ; \mathrm{B}, 15<\mathrm{DBH} \leqslant 25 \mathrm{~cm} ; \mathrm{C}, \mathrm{DBH}>25 \mathrm{~cm}$

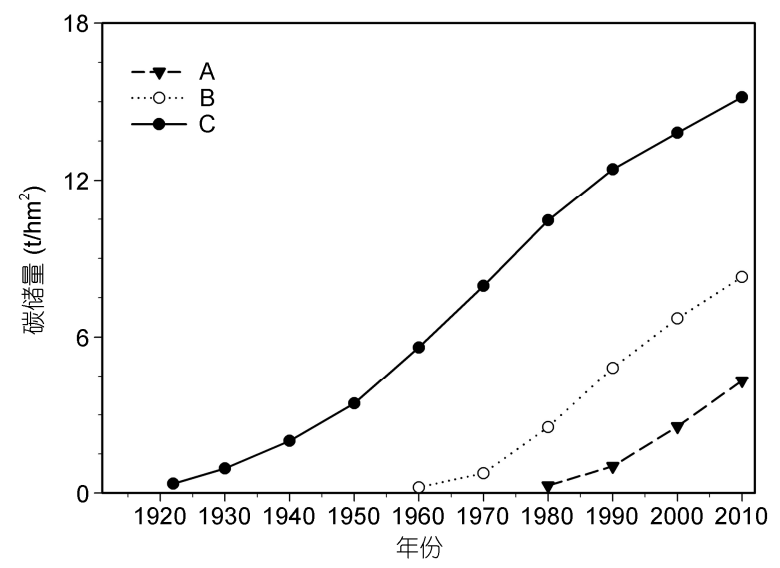

图 6 不同生长时期华山松碳储量的累计增长量 $\mathrm{A}, \mathrm{DBH} \leqslant 15 \mathrm{~cm} ; \mathrm{B}, 15<\mathrm{DBH} \leqslant 25 \mathrm{~cm} ; \mathrm{C}, \mathrm{DBH}>25 \mathrm{~cm}$
近, 不同径级华山松的碳储量逐年平稳增加.

\section{3 讨论}

\section{1 不同径级华山松生长变化特征}

本文所调查的样地包括了宝天曼不同径级的华 山松, 具有广泛的代表性, 能反映出华山松种群不同 林龄的生长变化. 对于大多树种来说, 树木生长的径 级结构与年龄结构是相对应的，很多学者在进行树 木生长研究时, 常采用树木径级结构代替树龄结构 分析树木生长的年龄动态 ${ }^{[26]}$. 利用树木年轮研究华 山松不同径级胸径年生长量的变化规律，结果与同 类研究结果相似 ${ }^{[27]}$, 都表现为树木径向生长先增后 


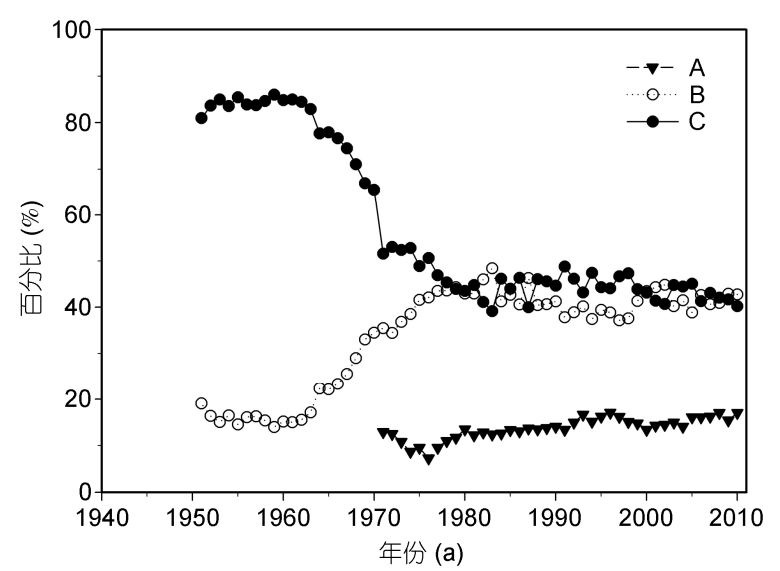

图 7 宝天曼不同径级华山松 $\mathbf{B C D}_{i} / \mathbf{B C D}_{n}$ 年态变化

A, B, C 表示不同径级, 其中 A, DBH $\leqslant 15 \mathrm{~cm} ; \mathrm{B}, 15<\mathrm{DBH} \leqslant 25 \mathrm{~cm}$; C, $\mathrm{DBH}>25 \mathrm{~cm} . \mathrm{BCD}_{i}$, 某一径级华山松某年的碳储量之和, $\mathrm{BCD}_{n}$ 同一 径级华山松的年增长碳储量的总和

减、再缓慢减小的趋势 ${ }^{[28]}$, 生长量的变化符合一般树 木生长的“S”型变化规律 ${ }^{[29]}$. 这种趋势是由于胸径和 树高生长在幼年时生长很快, 随着树龄增长, 胸径和 树高生长有所减缓，但依旧保持较快的增长趋势.

华山松幼苗幼树生长在树冠层下, 光照时间短, 生长缓慢; 中等径级华山松在树冠以上生长, 生境条 件基本能得到满足, 生长速率快; 大径级华山松由于 生理作用生长减慢 ${ }^{24]}$. 在本研究中, 树木年轮分析仪 能够很精确测量到每年的年轮宽度增长值, 而且定年 准确, 测量的小径级华山松胸径生长量高于方艾等 人 ${ }^{[24]}$ 研究的华山松胸径生长量, 可能的原因是: (1) 样地华山松为疏林, 透光、通风比较好; (2) 山地环境 中树木的早期生长具有物种特异性, 不同物种或类群 植物在同样环境下表现有差异 ${ }^{[30,31]}$; (3) 同一植物个 体在不同发育阶段, 对于同样的环境变化也可能有不 同乃至相反的响应.

\section{2 不同径级华山松生物量和碳储量研究}

本研究中 $1 \mathrm{hm}^{2}$ 标准样地的华山松生物量为 $54.75 \mathrm{t} / \mathrm{hm}^{2}$, 低于全国华山松平均生物量不同的估计 值 $71.83^{[32]}, 85.79^{[33]}, 79.67 \mathrm{t} / \mathrm{hm}^{2[25]}$. 造成这种差距的 原因可能有以下几个方面: (1) 森林中华山松密度不 同, 本样地华山松密度为 377 株 $/ \mathrm{hm}^{2}$, 远低于以上研 究者的 957 1366 株/ $/ \mathrm{hm}^{2}$; (2) 生物量估算方法不同, 方精云等人 ${ }^{[32]}$ 所用 $\mathrm{BEF}$ (生物量因子转化法), 马明等 人 ${ }^{[33]}$ 所用标准木法; (3) 本样地平均为 55 年树龄, 高 于陈存根 ${ }^{[25]}$ 的 30 年林龄华山松样地. 除去密度因素,
本实验样地华山松碳储量高于全国华山松平均生物 量的估计值, 可能是由林龄原因导致生物量的这种 差异. 越来越多研究认为, 森林中老龄林 ${ }^{[34]}$ 以及个 体最大者 ${ }^{[35]}$ 控制着森林生物量和碳储量的变化.

以树木年代学为基础研究森林生物量和碳储量, 树木轮宽值和树高的增长是碳储量年增长量的决定 因子, 胸径和树高拟合方程建立后, 只考虑轮宽值的 增长, 单株华山松的碳储量随着林龄的增加而增加. 3 个径级中, 大径级华山松总体碳储量最高, 这能很 好地解释为什么森林生态系统中老龄树仍然起着碳 汇的作用 ${ }^{[36-38]}$. 大径级华山松和中径级华山松的碳 储量年增加量在 1980 年后处于一个相等水平, 而小 径级华山松碳储量年增量一直处于一个较低水平, 产生这种原因的情况有：(1) 大径级华山松在 71 80 年达到第 2 个生理生长高峰, 达到 80 年后的 10 年间 生理生长下降导致碳储量下降. 中、小径级的华山松 在此 10 年间增长迅速, 生物量和碳储量在这一时期 迅速增长, 大径级华山松碳储量增长下降. (2) 中、小 径级树木的死亡减少了碳储量在 2000 2010 年间的 增加, 导致中径级和小径级华山松碳储量处于波动 水平. (3) 水的压强限制了树木的最大生长高度, 一 些个体较大的树其树高被限制生长以后, 树木轮宽 值的增长成为碳储量增长的主要限制因子. 水的压 强限制了树的最大高度假说(the hydraulic limitation hypothesis $)^{[39]}$ 得到了一些实例的支持 ${ }^{[40,41]}$.

树木年轮法在准确量化森林不同生长时期历史 碳储量研究时能够结合不同林龄之间树木径向生长 差异; 在对同一树种的碳储量进行深人研究时, 能够 考虑到同一树种不同地理种源、不同发育阶段、不同 自然地带的碳储量差异, 以及建立不同生物量树种 权重指标体系, 可以实现对生物量较为精确的估 测 ${ }^{[42]}$. Keeling 等人 ${ }^{[43]}$ 还结合树种生理学特性(耐荫性) 对于碳储量的影响进行了研究, 结果表明喜光性树 种可以获取更多碳储量.

\section{4 结论}

本文采用宝天曼国家级自然保护区 3 个不同径 级华山松树芯样本, 利用树木年轮宽度资料分析了 不同径级华山松的碳储量动态变化. 研究发现小径 级、中径级、大径级华山松碳储量分别为 $2.757,9.211$, $15.408 \mathrm{t} / \mathrm{hm}^{2}$; 虽然中径级华山松林分密度和径向生 长量最大, 但其碳储量年增长量和总量都低于大径 
级华山松. 结果说明, 在宝天曼华山松林中最大径级 的华山松控制着华山松林碳储量的增长; 中径级华 山松 $6.3 \%$ 的死亡率使得这一径级碳储量增长受到限 制; 小径级华山松林龄较小, 相对于中、大径级的华
山松没有竞争优势，其年均生物量稳速增加；随着林 龄的增长, 宝天曼华山松林碳汇作用会越来越高. 研 究表明利用树木年代学知识能较好地探讨宝天曼华 山松生长趋势和评估碳储量的动态变化.

\section{参考文献}

1 IPCC. 2006 IPCC Guidelines for National Greenhouse Gas Inventories. Agriculture, Forestry and Other Land Use, vol. 4. National Greenhouse Gas InventoriesProgramme, IGES, Japan. 2006

2 Emily M, Payen R, Rohweder M, et al. Pilot Analysis of Global Ecosystem: Forest Ecosystems. World Resource Institute, 2000

3 张远东, 刘彦春, 刘世荣, 等. 基于年轮分析的不同恢复途径下森林乔木层生物量和蓄积量的动态变化. 植物生态学报, 2012, 36: $117-125$

4 Fang J Y, Chen A P, Peng C H, et al. Changes in forest biomass carbon storage in China between 1949 and 1998. Science, 2001, 292: $2320-2322$

5 Liu Y F, Yu G R, Wen X F, et al. Seasonal dynamics of $\mathrm{CO}_{2}$ fluxes from sub-tropical plantation coniferous ecosystem. Sci China Ser D Earth Sci, 2006, 49(Suppl): 99-109

6 Cao M K, Woodward F I. Dynamic responses of terrestrial ecosystem carbon cycling to global climate change. Nature, 1998, 393: 249-252

7 Gong P. Progression of RS-ecometrics. J Nat Resour, 1999, 14: 51-54

8 Bouriaud O, Brdda N, Dupouey J L, et al. Is ring width a reliable proxy for stem-biomass increment? A case study in European beech. Can J Forest Res, 2005, 35: 2920-2933

9 Fritts H C. Reconstruction Large-Scale Climatic Patterns from Tree-Ring Data. Tucson, USA: The Uiversity of Arizona Press, 1991

10 Brienen R J W, Zuidema P A, The use of tree rings in tropical forest management: Projecting timber yields of four Bolivian tree species. Forest Ecol Manag, 2006, 226: 256-267

11 Hasenaur H, Nemani R R, Schadauer K, et a1. Forest growth response to hanging climate between 1961 and 1990 in Austria. Forest Ecol Manag, 1999, 122: 209-219

12 Hunt E R J, Martin F, Running S. Simulating the effects of climatic variation on stem carbon accumulation of a Pinus ponderosa stand: Comparison with annual growth increment data. Tree Physiol, 1991, 9: 161-171

13 Krakauer N Y, Randerson J T. Do volcanic eruptions enhance or diminish net primary production? Evidence from tree rings. Glob Biogeochem Cycles, 2003, 17: 1118

14 Cheikh M, Sophan C, Bienvenu S, et al. Potential of dendrochronology to assess annual rates of biomass productivity in savanna trees of West Africa. Dendrochronologia, 2013, 31: 45-51

15 邵全琴，杨海军，刘纪远，等.基于树木年轮信息的江西千烟洲人工林碳蓄积分析. 地理学报, 2009, 64: 69-83

16 Liu Y, Zhang Y, Liu S. Aboveground carbon stock evaluation with different restoration approaches using tree ring chronosequences in Southwest China. Forest Ecol Manag, 2012, 263: 39-46

17 张远东, 刘彦春, 刘世荣, 等. 基于年轮分析的不同恢复途径下森林乔木层生物量和蓄积量的动态变化. 植物生态学报, 2012, 36: $117-125$

18 Aide T M, Zimmerman J K, Pascarella J B, et al. Forest regeneration in a chronosequence of tropical abandoned pastures: Implications for restoration ecology. Restorat Ecol, 2000, 8: 328-338

19 Chazdon R L, Letcher S G, Breugel V M, et al. Rates of change in tree communities of secondary neotropical forests following major disturbances. Phil Transact R Soc Lond Ser B Biol Sci, 2007, 362: 273-289

20 Saldarriaga J G, West D C, Tharp M L, et al. Long-term chronosequence of forest succession in the upper RioNegro of Colombia and Venezuela. J Ecol, 1988, 76: 938-958

21 Pumijumnong N. Dendrochronology in Southeast Asia. Trees, 2013, 27: 343-358

22 代力民, 孙伟中, 邓红兵, 等. 长白山北坡椴树阔叶红松林群落主要树种的年龄结构研究. 林业科学, 2002, 38: 73-77 
23 Fritts H C. Tree Rings and Climate. London: Academic Press, 1976

24 方艾. 华山松林. 见: 《河南森林》编辑委员会, 编. 河南森林. 北京: 中国林业出版社, 2000

25 陈存根. 秦岭华山松林生产力的研究华山松林乔木层的生产量. 西北林学院学报, 1984, 1: 1-18

26 洪伟, 王新功, 昱承祯, 等. 濒危植物南方红豆杉种群生命表及谱分析. 应用生态学报, 2004, 15: 1109-1112

27 封晓辉, 程瑞梅, 肖文发, 等. 基于日均温度的华山松径向生长敏感温度研究. 生态学报, 2012, 32: 1450-1457

28 吴祥定. 树木年轮与气候变化. 北京: 气象出版社, 1990

29 赵志江, 谭留夷, 宁佐梅, 等. 王朗自然保护区怅江冷杉(Abies faxoniana)树干解析研究. 西北林学院学报, 2012, 27: 163-168

30 储子彦. 亚热带 39 种植物的叶碳效率对环境因子的响应研究. 硕士学位论文. 杭州：浙江大学, 2008

31 Bin Y, Lin G J, Li B H, et al. Seedling recruitment patterns in a 20-ha subtropical forest plot: Hints for niche-based processes and negative density dependence. Eur J Forest Res, 2012, 131: 453-463

32 方精云，刘国华，徐嵩龄. 我国森林植被的生物量和净生产量. 生态学报, 1996, 16: 497-508

33 马明, 王得祥, 刘玉民. 秦岭天然华山松林碳素空间分布规律及其动态变化. 林业资源管理, 2008, 5: 75-78

34 Liu Y, Yu G, Wang Q, et al. How temperature, precipitation and stand age control the biomass carbon density of global mature forests. Glob Ecol Biogeogr, 2014, 23: 323-333

35 Stegen J C, Swenson N G, Enquist B J, et al. Variation in above-ground forest biomass across broad climatic gradients. Glob Ecol Biogeogr, 2011, 20: 744-754

36 Phillips O L, Malhi Y, Higuchi N, et al. Changes in the carbon balance of tropical forests: Evidence from long-term plots. Science, 1998, 282: 439-442

37 Luyssaert S, Schulze E D, Börner A, et al. Old-growth forests as global carbon sinks. Nature, 2008, 455: 213-215

38 Lewis S L, Lopez-Gonzalez G, Sonké B, et al. Increasing carbon storage in intact African tropical forests. Nature, 2009, 457: 1003-1006

39 Midgley J J. Is bigger better in plants? The hydraulic costs of increasing size in trees. Trends Ecol Evol, 2003, 18: 5-6

40 Koch G W, Sillett S C, Jennings G M, et al. The limits to tree height. Nature, 2004, 428: 851-854

41 Ryan M G, Phillips N, Bond B J. The hydraulic limitation hypothesis revisited. Plant Cell Environ, 2006, 29: 367-381

42 Naidu S L, Delucia E H, Thomas R B. Contrasting patterns of biomass allocation in dominant and suppressed loblolly pine. J Forest Res, 1998, 28: 1116-1124

43 Keeling H C, Baker T R, Martinez R V, et al. Contrasting patterns of diameter and biomass increment across tree functional groups in Amazonian forests. Oecologia, 2008, 158: 521-534

\title{
Carbon storage dynamics of Pinus armandii forest at different diameter levels based on tree ring data in the Baotianman National Nature Reserve, central China
}

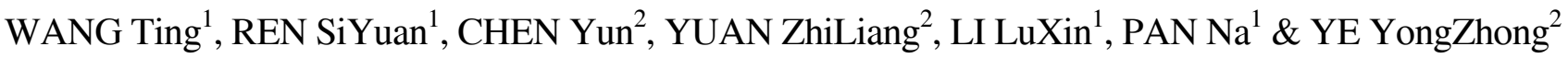 \\ ${ }^{1}$ College of Forestry, Henan Agricultural University, Zhengzhou 450002, China; \\ ${ }^{2}$ College of Life Sciences, Henan Agricultural University, Zhengzhou 450002, China
}

Based on tree-ring analysis, Pinus armandii trees were divided into three classes (A, DBH $\leqslant 15 \mathrm{~cm} ; \mathrm{B}, 15 \mathrm{~cm}<\mathrm{DBH} \leqslant 25 \mathrm{~cm} ; \mathrm{C}, \mathrm{DBH}$ $>25 \mathrm{~cm}$ ) to study carbon storage dynamics of Pinus armandii populations in the Baotianman National Nature Reserve. Comparison of these three diameter classes revealed three major findings. (1) The carbon storage of $P$. armandii trees in small DBH class A, intermediate class B and large class C were $2.757,9.211$ and $15.408 \mathrm{t} / \mathrm{hm}^{2}$, respectively, with corresponding annual carbon increments of $0.0685,0.1535$ and $0.136 \mathrm{t} / \mathrm{hm}^{2}$. (2) The intermediate class $(15 \mathrm{~cm}<\mathrm{DBH} \leqslant 25 \mathrm{~cm})$ had the highest stand density, diameter increment and carbon storage among the three DBH classes in the $P$. armandii forest. (3) Trees in the large DBH class $(\mathrm{DBH}>25 \mathrm{~cm})$ had the greatest contribution to total carbon storage of the $P$. armandii forest. Tree mortality was the main factor limiting carbon storage within small and intermediate DBH class $P$. armandii trees, whereas physiological growth was the restrictive factor for large DBH class trees. Our results demonstrate that dendrochronological analysisis is an important method to evaluate growth trends and to assess the carbon storage dynamics of the $P$. armandii forest in the Baotianman National Nature Reserve.

Pinus armandii, tree ring, DBH class, carbon storage, dynamics

doi: 10.1360/N972014-00403 